\title{
ESTIMATING THE AMOUNT OF THE WASTED WATER DUE TO FAULTY ACTIVITIES IN SOME AREAS IN DHI QAR/ SOUTHERN IRAQ
}

\author{
${ }^{1}$ Hussein Khalefa Chlaib, ${ }^{2}$ Jalal Hameed Ali \\ ${ }^{3}$ Najm Abed Yasir, ${ }^{4}$ Alaa Ibrahim Badi, ${ }^{5}$ Jaber Hameed Muttair \\ 1,2,3,4,5 Department of Soil Sciences and Water Resources, Collage of Agriculture, University of Sumer, Dhi-Qar, Iraq
}

Email: hkaldobayany@yahoo.com

\begin{abstract}
:
Because of the poor water situation in Iraq in general and the southern governorates in particular requires prior consideration to find appropriate solutions. In this study، the researchers sought to estimate the amount of waste water in irrational and irrational ways in five vital areas within Thi-Qargovernorate, which are Qalat Suker, Al-Rifai, Al-Shatrah, Sug Al-Shuyukh and Al-Fuhud cities using the questionnaire distributed to citizens. The total amount of water wasted per month in these five areas due to the unemployed faucets is 1752660 liters. Because of the leakage of the water reservoirs without a roving، it is 901906480 liters because washing the cars with the water hose is 952632 liters and keeping the faucets open during the cleaning of the teeth is 288845180 liters. Khartoum is 23163505 liters. The researchers concluded that very large quantities of drinking water are wasted daily due to erroneous activities by the population in the study areas where 1216620475 (one billion two hundred and sixteen million six hundred and twenty five hundred) liters per month are lost. Given that the average person in developing countries may need about 80 liters per day for all his needs، these amounts would have been wasted if it was used to provide 510000 citizens a day with drinking water
\end{abstract}

Keywords: WATER, WATER WASTING, TEETH CLEANING, GARDENS WATERING, USELESS FAUCETS 


\section{INTRODUCTION}

Allah almighty explained in the holy glorious book in many ayat such as in "Surat Al-Anbiya 'verse 30" that is water is the cause of life because Allah Almighty made water as the life. Water is important element for the life of human and his daily activities, animals and plant (even with saline water) (Abbas et al., 2018; Hussein, et al., 2019; Al-Khafaji and Al-Janabi, 2020). All Arab countries are depend on rivers flowing in their lands and their sources are located outside their borders, as in Egypt, Sudan, Syria and Iraq, and this threatens the water interests of these countries, and the increase in demand for water from all sides in a way that is not compatible with the serious pursuit of finding new sources of water is a dangerous thing that may happen. A profound imbalance between supply and demand for water, and the truth is that water is not like other commodities, as it is not possible to increase the supply of it to meet the high demand for it, and from here it is necessary to control the demand and rationalize consumption with the development of water sources, and the truth is that pure water is heading towards recession and the Middle East with its Arab countries is a potential conflict focus (Omar, 2006).International reports have indicated that one person out of five individuals in the world (An average of 1.2 billion people are deprived of water, and one of two (about 3 billion people) use impure water (Omar, 2006). Conferences and seminars have been held that dealt with the issue of water, but it is still few when compared to the size and importance of the topic, and the need for awareness about it increases from time to time. Among the studies that have appeared on this topic:

1- A study of the dangers of the water crisis by Dr. Nazeer Al-Ansari / 2018 entitled "Risks of the water crisis in Iraq: causes, solutions and ways of treatment" (Al-Ansari, 2018).

2- An expanded report by Prof. Haider Hussain Al Tuama, 2018 entitled (The Water Crisis in Iraq: Causes and Solutions), (Al-Tuama, 2018).

3- An Iraqi, Swedish and German research team consisting of Professor Nazeer Al-Ansari, Professor Nusrat Admo, Professor Varujian Sisakyan, Professor Sven Kentson, Professor John Lowe and Dr. Sadiq Baqer Al-Jawad, worked on publishing 10 papers on the water resources crisis of the Tigris and Euphrates in Iraq, (Al-Miqdadi, 2018).

4-Dr. Salah Abdel Badi Al-Shalabi, (Al-Shalabi, 1999) studied the problem of fresh water within the framework of the new international agreement.

5- Abd Al-Hamd Othman explained the Islamic principles in the environment and development, especially in water use rationalizing.

6- Qais Al-Obaidi, 2011, indicated that one of the most important methods and of rationalizing water consumption in various fields is a joint relationship between the people and the state, (Al-Obaidi, 2011).

7- Many scientific papers and researches were published in last decades which explained the ability of using different sources of water in agriculture such as drainage water (Al-Qasimi and Al-Salhi, 2018),sewage-treatment plant water (Wotaify and AlMamuri, 2019). Also, there were many researched had been done to increase the efficiency of water such as using magnetic water in agriculture (Joody, 2016). 


\section{Research objective}

Through this study, the researchers seek to estimate the amount of wasted water due to unjustified and irrational ways in five cities within Thi-Qar governorate, which are Qalat Suker, Al-Rifai, Al-Shatrah, Sug Al-Shuyukh and Al-Fuhud. Also, directing recommendations to the relevant government departments and people to reduce this waste according to the estimates concluded by this study.

\section{Study area}

The study included five cities within Thi-Qar governorate, which are Qalat Suker, Al-Rifai, Al-Shatrah, Sug Al-Shuyukh and Al-Fuhud cities, Figure 1. Qalat Suker is one of Thi-Qar governorate cities in Iraqi. It is located on the banks of Al-Gharraf River, which branches off the Tigris River at the city of Kut. The population of the city is about 110,000 people. It located about $100 \mathrm{~km}$ away from the city of Nasiriyah and $260 \mathrm{~km}$ from Baghdad, its climate is moderate. Al-Rifai city is one of the important large cities, and it is about $300 \mathrm{~km}$ south of the capital Baghdad, and about $80 \mathrm{~km}$ north of Nasiriyah. its population is about 200.000 people. Al-Shatra city is a district center located in Thi-Qar governorate. Its population is 254,000 people according to the 2014 census. Sug Al-Shuyukh is a city located in the south part of Thi-Qar, and has a population of 200.000 people. It was called Souk Al-Nawashi (Najdi, 1912). Al-Fuhud sub-district is affiliated with the administrative district of Al-Chibayish, with a population of 91,000people according to the 2014 census, and it is about $65 \mathrm{~km}$ east from its center, Nasiriyah, and about $35 \mathrm{~km}$ west of Al-Chibayish.

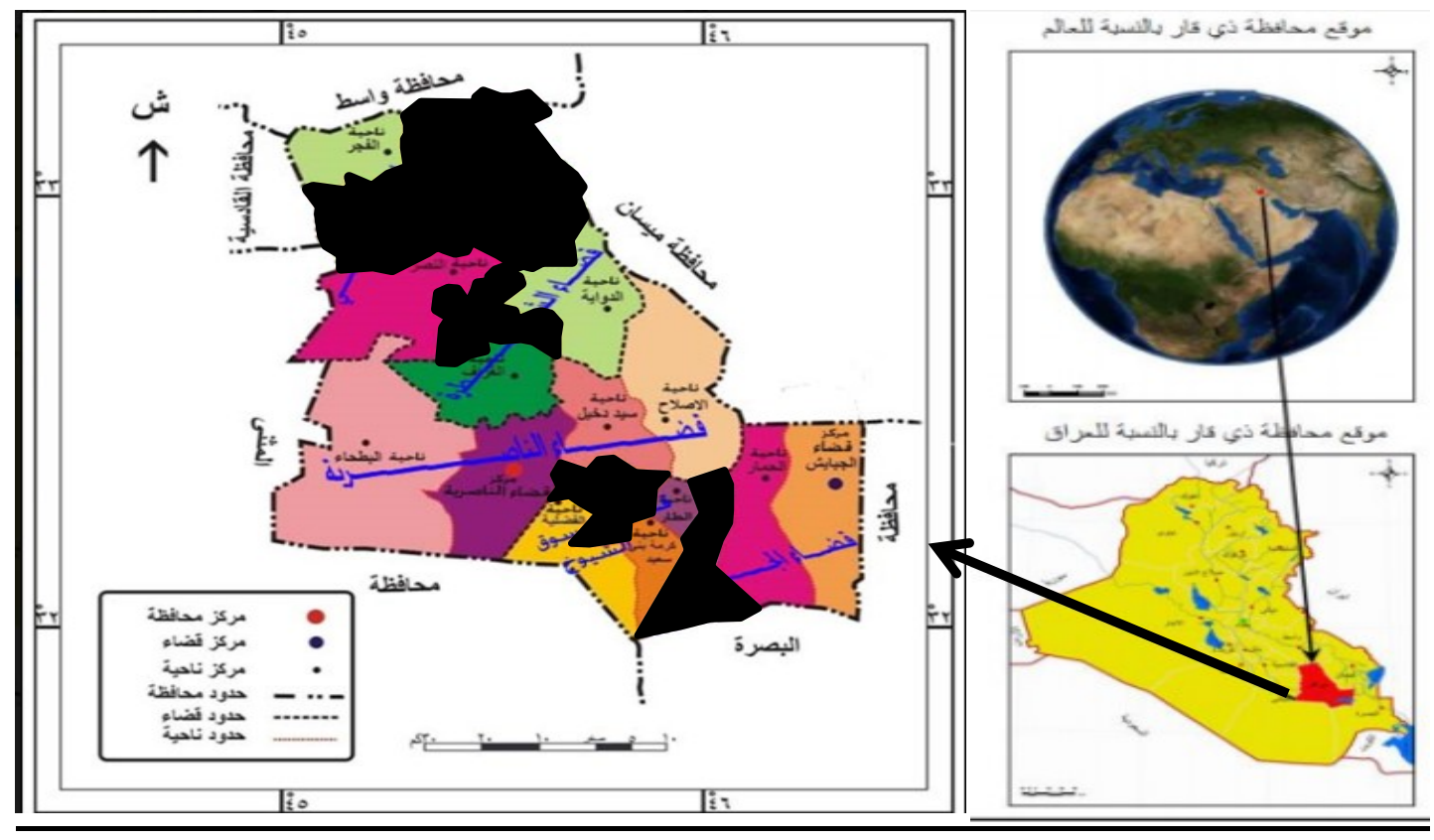

Figure (1) Shows the study areas on Thi-Qar governorate, Iraq and the world maps, which are represented by the black areas.

\section{UTJagr}




\section{MATERIALS AND METHODS}

\section{The questionnaires}

This research was based on the questionnaire, as three questionnaires were designed:

1- The first questionnaire includes information about the name of the administrative. Information of three parts, the first part includes general information about the family that includes the number of individuals, the number of water taps (total faucets), the number of broken water taps and the number of water tanks in the housing unit. The second part includes information about the individuals who use the toothbrush and who leave the faucets open while brushing and the approximate period in minutes that a single person takes during the cleaning process. The third part includes information on water wasted due to watering the gardens using drinking water, while the fourth part includes information about the water tanks in the housing units, their numbers and some of their specifications. The questionnaire also included important notes for citizens about the research's importance. The research also included a distribution of a second questionnaire for people who own cars, it included important notes on the research topic and its social importance. The questionnaire also included the answer of two questions:

Do you wash the car using a bucket and roller? Yes or No?

Do you wash the car using a hose? Yes or No?

If the answer is yes, how many hours does the washing process take?

The research also included other additional information about the population of the area covered by the distribution of previous questionnaires, and the number of regular and random housing units in the studied administrative unit.

\section{Calculation formulas used to obtain research information}

For the purpose of obtaining the total numbers of idle faucets and the amount of water lost due to them; the total number of careless people who leave the faucets opened during teeth cleaning and the quantities of water wasted because of them; the number of tanks without a raft and the amount of wasted water due to; the amount of water wasted due to washing cars and watering gardens with a hose and all the related numbers, many formulas were obtained.

Note: the partial number is the number studied in the questionnaires.

The careless people are people who leave the faucets running while brushing their teeth.

The partial time is the studied time by the questionnaires.

\section{Equations for calculating the total number of idle taps in the administrative unit and the amount of water lost per} month:

The total number of idle taps in the administrative unit $=($ The partial number of the idle taps $*$ The total number of the administrative units ) /The partial number of the administrative unit. 
Formulas for calculating the total number of people who leave the faucets running while brushing the teeth and the monthly amount of water lost due to them.

The total number of the careless people $=($ The partial number of the careless people $*$ The total number of the people using teeth brush)/The partial number of the people using teeth brush

Time with minute daily:

The total consumed time (minute/day) $=($ The partial time consumed $($ minute/day) $*$ The total number of the careless people)/The partial number of the careless people.

Considering that a person uses the brush twice daily, the total consumed time (minute / day) is multiplied by 2 to get the time with minute per day.

To get the consumed time per month, the time is multiplied by 30 days.

Equations for calculating the total number of water tanks in the administrative unit, the number of the studied tanks, the number of tanks without a raft, and the amount of water lost per month due to the absence of floats.

The total number of the tanks without a raft $=($ The partial number of the tanks without a raft $*$ The total number of the administrative unit)/The partial number studied tanks....(4)

Then we calculate the amount of water seepage from the tank per minute.

The amount of water lost from tank/day $=($ The amount of water lost from tank/minute $*$ The mean of the water seepage period).

The total amount of water lost from all tanks/month $=($ The amount of water lost from tank/day $*$ The total number of the tanks without a raft $) * 30$

To get the average number of car washes by hose, we used the following equation:

The average of car washing times $=($ The number of washing in summer + the number of washing in winter )$/ 2$.

To get the washing time per month, we multiply the washing time by 4

To calculate the amount of water lost due to washing cars per month, we use the following equation: 
The total amount of lost water $/$ month $=$ washing time $($ minute/month $) *$ water amount in

liter/minute

\section{Calculation of water losses in Al-Shatra city:}

Water lost due to tank seepage without raft

The partial Number of tanks $=280$

The partial number of tanks without a raft $=119$

The Total number of tanks $=3840$ tanks

The total Number of tanks without raft $=1020$ tanks

The partial seepage time from tanks without raft $=1342 \mathrm{~min}$

The total seepage time from tanks without raft $=11053 \mathrm{~min}$

The total seepage time for all tanks $=103527$ minutes $/$ day $=3105810$ monthly minutes

Amount of water lost as a result of tanks seepage without raft $=37,269,720$ liters $/$ month

Water lost due to the idle faucets

Total number of idle faucets $=1,385$ faucets

Amount of water lost due to idle faucets $=83,100$ liters $/$ month

Water lost from faucets running during the tooth-cleaning

The partial number of people $=1355$

The partial number of people using the brush $=882$

The partial number of careless individuals $=407$

Time for leaving the faucets running during the tooth cleaning $=525$ minutes

The total number of users $=227823$ people

The total number of careless people $=105,129$ people

The total Time of leaving the faucets running during the cleaning teeth by careless $=271217$ minutes $/$ day $=8136220$

minutes / month

The amount of water lost as a result of leaving the faucets running during the tooth-washing $=16272440$ liters $/$ month

Water lost as a result of watering gardens with drinking water

The partial Number of gardens $=80$

The total number of gardens $=1097$ gardens

The time of watering the gardens $=7397$ minutes

The number of watering times $=245$ times $/$ week

Total watering time for gardens $=101431$ minutes $/$ week $=405724$ minutes $/$ month

The amount of water lost as a result of watering gardens with drinking water $=2434344$ liters $/$ month 


\section{Water lost as a result of washing cars by hose}

The partial number of cars $=104$

Average number of washings $=310$ times $/$ week

Washing time $=5640$ minutes $/$ week

Washing time per month $=22560$ minutes $/$ month

The amount of water lost as a result of washing cars with hose $=135360$ liters / month

\section{Water amount losses in Al- Rifai city:}

The number of regular housing units is 10,000

The number of random housing units is 5000

Water lost due to water seepage from the tank without a raft

Partial number of studied tanks $=399$

partial number of tanks without raft $=332$

Total number of tanks $=23,940$ tanks

Total number of tanks without a raft $=12481$ tanks

The amount of water leaked out per month due to tanks without a raft $=44,241,480$ liters $/$ month

Water lost due to idle faucets

Partial number of idle faucets 214

Total number of idle faucets $=12840$ faucets

So, the amount of water lost from all the idle faucets $=25680$ liters $/$ day

And the waste water per month $=770400$ liters $/$ month

Water lost as a result of leaving the faucets running during the washing teeth

Partial number of individuals $=2029$

Partial number of people using the brush $=839$

Partial number of the careless individuals $=598$

Total number of brush users $=82,700$

The total number of careless people $=58,945$

So the amount of water lost as a result of keeping the faucets open while brushing the teeth $=232,783,200$ liters / month

Water lost as a result of watering gardens with drinking water

The partial number of gardens is 124

The partial time of studied watering 7971

The number of studied watering times 358

The total number of gardens $=7440$ gardens

So the total water consumed due to watering the gardens with pure water $=11478240$ liters $/$ month 
Water lost as a result of washing cars by hose

The partial number of cars $=196$ cars

The average number of washings $=352$ times a week

The amount of water consumed $=76080$ liters $/$ month

\section{Calculation of water losses in Qalat Suker city:}

The number of housing units is 7000

\section{Water lost due to leakage of faulty faucets}

The partial number of idle faucets $=175$

The total number of idle faucets $=4454$

The amount of water lost due to leaking faucets $=8908$ liters $/$ day $=267240$ liters $/$ month

Water lost due to tank without float

The partial number of the tanks $=581$

The partial number of tanks without float is 392 tank

Total number of tanks without float $=4723$ tanks

Water lost due to tank seepage without raft $=1690840$ liters $/$ month

Water lost from faucets running during the tooth-cleaning

The partial number of individuals $=2143$

The partial number of people using the brush $=1179$

The partial number of careless individuals $=829$

The total number of careless people $=42,552$

Water lost due to leaving the faucets running during the tooth-washing process $=2553120$ liters $/$ month

Water lost as a result of watering gardens with drinking water

The number of watering time $=470$ times

partial Number of gardens $=123$

The total number of gardens $=3131$ gardens

The amount of water lost as a result of watering gardens with drinking water $=8247504$ liters $/$ month

Water lost as a result of washing cars by hose

The partial number of cars $=288$

The amount of water consumed per month $=426240$ liters $/$ month

\section{Calculation of water losses in Sug Al-Shuyukh city:}

Water lost due to tank seepage without raft

The partial number of tanks $=324$

Total number of tanks $=18720$ tanks 
The partial number of tanks without a raft $=227$ tanks

Total number of tanks without raft $=9949$ tanks

The amount of water seepage from tanks without a raft $=815817600$ liters $/$ month

\section{Water lost due to leakage of idle faucets}

The total number of idle faucets $=9062$

Water lost due to idle faucets $=543720$ liters $/$ month

Water lost as a result of leaving the faucets running during the tooth-cleaning

The partial number of people brushing their teeth $=1050$

The partial number of careless and studied individuals $=910$

The total number of careless people $=63025$

The amount of water lost as a result of leaving the faucets running during the tooth-brushing process $=34906140$ liters / month

Water lost as a result of watering gardens with drinking water

The partial number of studied gardens $=145$

The total number of gardens $=5065$ gardens

The amount of water lost as a result of watering gardens with drinking water $=618696$ liters $/$ month

\section{Water lost as a result of washing cars by hose}

The number of washing times $=7675$ washings $/$ week

Washing time $=7405$ minutes $/$ week $=29620$ minutes $/$ month

The amount of water lost as a result of washing cars by hose $=177720$ liters / month

\section{Calculating the water lost in Al-Fuhud city:}

The number of regular and random housing units is 3500

$\underline{\text { Water lost due to seepage from tank without a raft }}$

The partial number of tanks $=572$

The partial number of tanks without a raft $=480$

The total number of tanks without raft $=2937$ tanks

The amount of water lost as a result of tanks without a raft $=2886840$ liters $/$ month

Water lost due to the idle faucets

The partial number of idle faucets $=105$

Total number of idle faucets $=1470$ faucets

Amount of water lost due to idle faucets $=88200$ liters $/$ month 
Water lost as a result of leaving the faucets running during the tooth-cleaning

The partial number of individuals $=2261$

The partial number of people using the brush $=1689$

Total number of brush users $=36977$ people

The partial Number of careless individuals $=651$

The total number of careless people $=14,252$

The amount of water lost due to leaving the faucets running during the teeth cleaning $=2,330,280$ liters / month

Water lost as a result of watering gardens with drinking water

The total number of gardens $=2142$ gardens

The amount of water lost as a result of watering gardens with drinking water $=384720$ liters $/$ month

Water lost as a result of washing cars by hose

The partial number of cars $=165$

The amount of water lost as a result of washing cars by hose $=61152$ liters $/$ month

\section{RESULTS AND DISCUSSION}

The table below shows the quantities of wasted water due to the studied wrong activities of people, while Figure (2) shows the histograms of water quantities losses according to the cause of loss in the study areas. Figure (3) represents the total amount of water lost per month due to all the studied wrong activities.

Table (1) shows the quantities of wasted water due to wrong activities.

\begin{tabular}{|c|c|c|c|c|c|c|}
\hline Total & \multicolumn{5}{|c|}{ 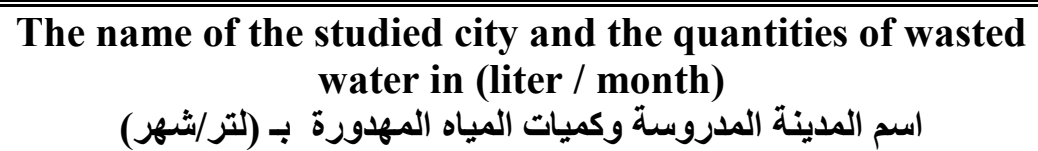 } & \multirow[t]{2}{*}{$\begin{array}{l}\text { Water waste } \\
\text { activities }\end{array}$} \\
\hline المجموع & $\begin{array}{c}\text { Al- } \\
\text { Shatra } \\
\text { الشطرة }\end{array}$ & $\begin{array}{c}\text { Al- } \\
\text { Fuhud } \\
\text { الفهود }\end{array}$ & $\begin{array}{c}\text { Sug } \\
\text { Al- } \\
\text { Shuyukh } \\
\text { سوق الثيوخ }\end{array}$ & $\begin{array}{l}\text { Qalaat } \\
\text { قلمعة سكر }\end{array}$ & $\begin{array}{c}\text { Al-Refaee } \\
\text { الرفاعي }\end{array}$ & \\
\hline 1752660 & $\overline{83100}$ & $\overline{88200}$ & $\overline{543720}$ & 267240 & $7 \overline{770400}$ & $\begin{array}{l}\text { Idle faucets } \\
\text { الحنفيات العاطلة }\end{array}$ \\
\hline 901906480 & 37269720 & 2886840 & 815817600 & 1690840 & 44241480 & $\begin{array}{l}\text { Tanks without a } \\
\text { raft } \\
\text { الخزانات بدون طوافة }\end{array}$ \\
\hline 952632 & 135360 & 61152 & 177720 & 426240 & 152160 & Car wash by \\
\hline
\end{tabular}




\begin{tabular}{|c|c|c|c|c|c|c|}
\hline & & & & & & 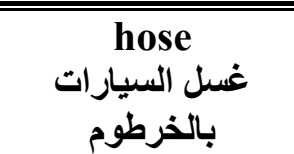 \\
\hline 288845180 & 16272440 & 2330280 & 34906140 & 2553120 & 232783200 & $\begin{array}{c}\text { Teeth Cleaning } \\
\text { تنظيف الاسنان }\end{array}$ \\
\hline 23163505 & 2434344 & 384720 & 618696 & 8247505 & 11478240 & $\begin{array}{c}\text { Watering } \\
\text { gardens with } \\
\text { drinking water } \\
\text { سقي الحدائق بمياه } \\
\text { الشرب }\end{array}$ \\
\hline 1216620457 & $\overline{56194964}$ & 5751192 & 852063876 & 13184945 & 289425480 & $\begin{array}{l}\text { Total } \\
\text { المجموع }\end{array}$ \\
\hline
\end{tabular}

It is clear from table 1 and figures 2 and 3 that the largest amount of wasted water in Al-Rifai city was due to teeth cleaning, while in Qalat Suker, garden watering dominated the largest percentage of wasted water, and in Sug Al- Shuyukh, Al-Fuhud and Al-Shatra, the seepage water from tanks without a raft were the biggest cause of water waste. The total amount of water wasted per month in these five areas due to idle faucets is 1,752,660 liters, and because of the seepage of water tanks without a raft is 901,906,480 liters, and because of washing cars by hose is 952,632 liters, and because of keeping the faucets open while cleaning the teeth is $288,845,180$ liters, and because of the garden watering with drinking water is $23,163,505$ liters. From the previous table, it can be seen that the largest waste water due to the idle faucets was in the Al-Rifai city and the least waste was in Al-Shatra city. Also, the largest waste water due to the seepage of water from the tanks without a float was in Sug Al-Shuyukh city and the least wastewater was in Qalat Suker city. The biggest waste water of washing cars by hose was in Qalat Suker and the least waste water was in Al-Fuhud city. As for the biggest waste water due to keeping the faucets open during the teeth cleaning it was in Al-Rifai city and the least waste water was in Al-Fuhud city. The largest waste water due to watering gardens by drinking water hose was in Al-Rifai city and the least wasted water was in Sug Al-Shuyukh city. These differences in the quantities of wasted water depend on many factors, including population density, the cultural level and the living levels of people. 


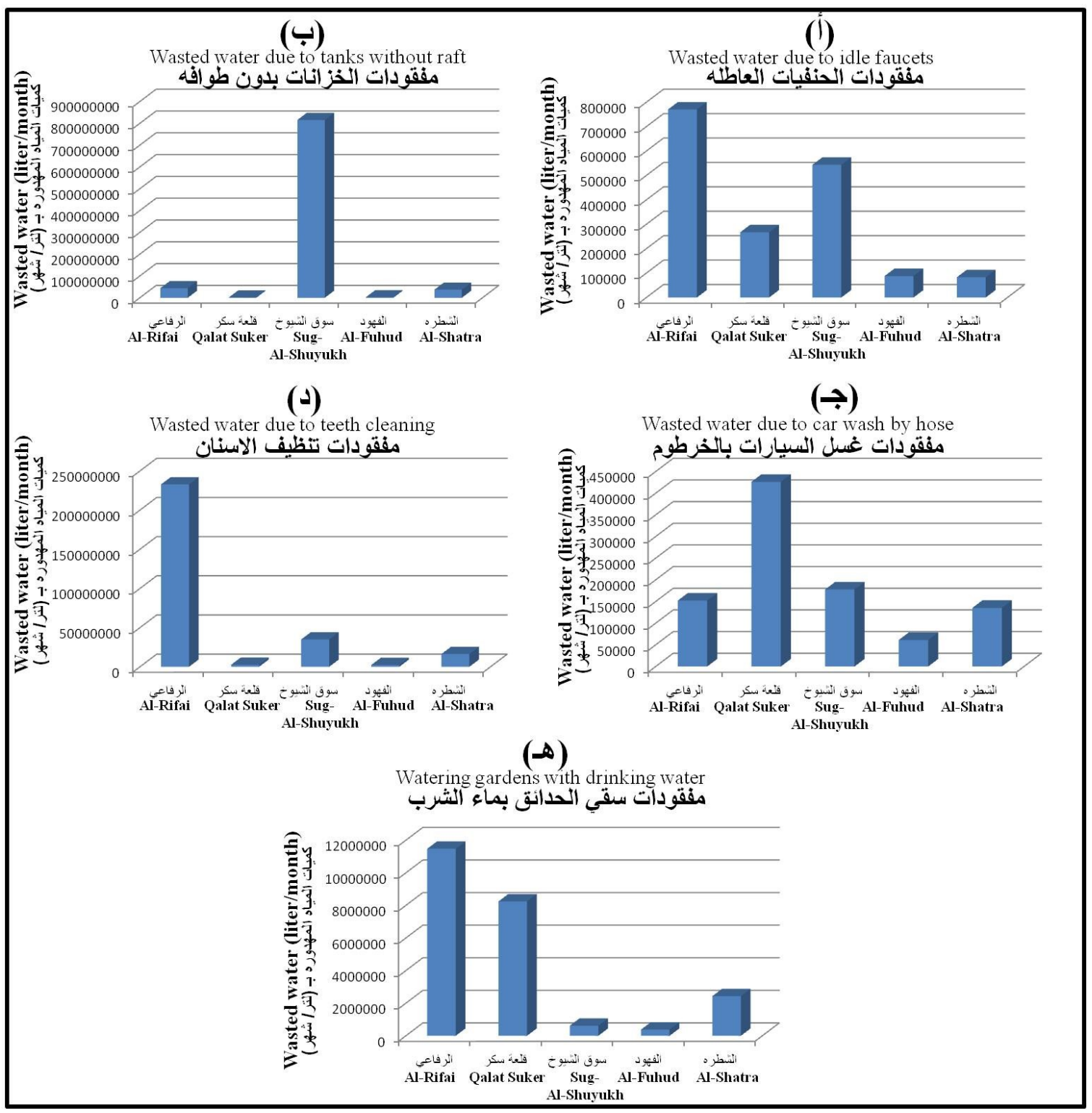

Figure (2) Shows the histograms of water losses according to the cause of loss in the study areas. 
University of Thi-Qar Journal of agricultural research

ISSN Onlin:2708-9347, ISSN Print: 2708-9339 Volume 10, Issue 1 (2021) PP 149-163

https://jam.utq.edu.iq/index.php/main $\quad$ https://10.54174/UTJagr.Vo10.N1/14

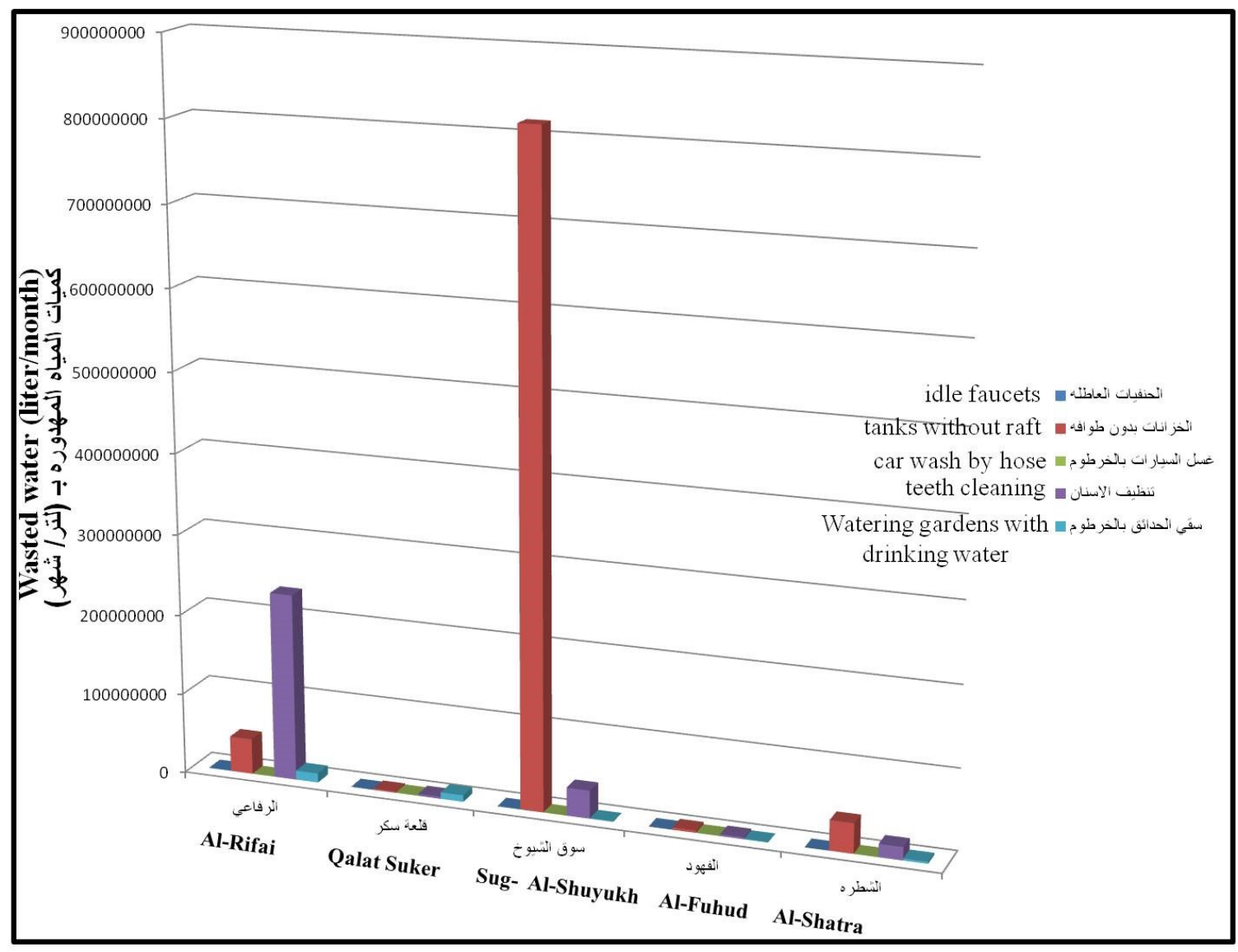

Figure (3) The total amount of water lost per month due to all the studied faulty activities.

\section{CONCLUSION}

The researchers conclude from this study that there are very large quantities of water wasted daily due to wrong activities by the population in the study areas, where an amount of approximately 1216620475 (one billion two hundred and sixteen million six hundred twenty thousand four hundred seventy five) liters is lost monthly. Assuming that the average person in developing countries may need approximately 80 liters per day for all his needs (2,400 liters per month), so these calculated wasted quantities if water, if used properly and without waste, would provide 507,000 citizens per day with safe drinking water. 


\section{Recommendations}

Researchers recommend the following:

1- Conducting other studies on other aspects and forms of water waste for the same areas and other areas.

2- Conducting awareness programs on the optimal use of water for all population groups.

3- Involve an educational subject about the optimal use of water within the curricula of primary and middle school.

4- Deliver these results to the relevant authorities to benefit from.

\section{REFERENCES}

1-Al Tuma, H. H. 2018. Water Crisis in Iraq, Causes and Solutions. Scientific report, Al Furat Center for Development and Strategic Studies, Strategic Studies Center, University of Karbala., in Arabic

2-www.yourhomegov.au. retrieved 12-9-2018.

3-Al-Ansari, N. 2018. Water Crisis Risks in Iraq, Reasons and Ways of Process. Scientific report, Al Jazeera Center for Studies, Al Jazeera Media Network, in Arabic.

4-Al-Najdi, S.B. Saleh. 1912. Suq Al-Shuyoukh city. Arabs Language Magazine 6 (2): 251-254 December, in Arabic.

5-Shalabi, S.A. 1999. The problem of fresh water in the term of the new international agreement. Journal of International Politics 35 (137): 8-44, in Arabic

6-Al-Obeidi, Q.H. 2011. Awareness and aquaculture. College of Basic Education Research Journal 11(1): 340-356, in Arabic

7-Othman, A.H. 2005. Islamic principles in environment and development. Journal of Islamic Thought and Scientific Creativity 3(3): 22-38, in Arabic

8-Ali, A. M. 1990. History of Suq Al-Shuyoukh City, Issam Press, Baghdad, Iraq, pp. 238, in Arabic

9-Omar, M. I. 2006. Water Treatment, Scientific Books House for Publishing and Distribution, Cairo, Egypt, in Arabic.

10-Al-Miqdadi, K. 2018. Iraqi Water Crisis in 10 Scientific Researches, Scientific report, Water Electronic Magazine.

11-Muaead F. Abbas Abdullah A. Abdullah Nadia N. Haamed. 2018. Effect of the salinity of irrigation water and spraying with selenium in the yield indicators and the qualitative traits for two cultivars of the Okra plant (Abelmoschus esculentus L.) cultivated in greenhouses. Euphrates Journal of Agriculture Science-10(2): 295 - 306.

12- Hussein, S.A., Al-joubory, H.R., Sahib, M. M. 2019. Effect of bio-fertilization and salinity levels of irrigation water on the growth and yield traits of wheat. Euphrates Journal of Agriculture Science. 11 (3): 39-48.

Page162

\section{UTJagr}


13- Al-Khafaji, M.J.M. and Al-Janabi, H.Y.A. 2020. Effect of salinity of irrigation water and spraying with selenium and Humic acid on the growth of yellow corn. Euphrates Journal of Agriculture Science 12 (1): 76-84.

14- Al- Wotaify A.S. S. and Al-Mamuri Z. A. S. 2019. Bioaccumulation for some heavy metals on the impact of irrigating soil and plant with wastes of Al-Muamirah station. Euphrates Journal of Agriculture Science 11 (1): 22 - 32.

15- Al-Qasimi, H. A. A. and Al-Salhi,Th. H. Kh. 2018. The effect of agriculture media and the quality of irrigation water in the

pomegranate leaves content (Wonderful and Salimi cultiars) of some

mineral elements. Euphrates Journal of Agriculture Science 10(2): 124-136.

16- Joody, A. T. 2016. Effect of GA3 ,foliar fertilizer growmore and magnetic treated water on growth of apple sapling cv Ann. The third agricultural conference. Euphrates Journal of Agriculture Science 272-282. 